\title{
Tariq Ali, The Dilemmas of Lenin: Terrorism, War, Empire, Love, Revolution (London and New York: Verso, 2017). 373 pp. Paperback \$23.00.
}

"Why Lenin?" Or, so Tariq Ali asks on the first line Dilemmas of Lenin, his recent reassessment of Lenin and Leninism. The answer, the reader is told, seems deceptively simple: "[t] his book was written to put Lenin in proper historical context" (ix). Two implications follow from this. First, Dilemmas of Lenin represents Ali's own efforts to mark, and think through, the historical implications of 1917. For Ali, it is important to understand the factors that led Russian communist revolutionaries to engineer "a frontal assault on capitalism and its empires" (1). Second, Ali's study is a form of public and activist education that points beyond the deep morass into which contemporary public life has fallen. Said differently, Ali asks his readers to follow his thinking as he explores the factors that made this "frontal assault" possible and which, ultimately, led to its Stalinist perversion. In telling this story, Ali wants his readers to note several key points which emerge as dilemmas. These take the form of choices Lenin and other revolutionaries needed to make that were part and parcel of their politics, but which did not admit easy solutions. Dilemmas emerge, Ali seems to suggest by implication, as part of an unfolding historical process in which socialists in 1917 find themselves on qualitatively new ground. Dilemmas of Lenin is a "big book" in the sense that it is making a range of different points but three stand out as particularly significant.

First, Ali's narrative looks to unapologetically reclaim Bolshevism-particularly but not exclusively, its aspirations - for the left by asking his readers to consider its political meaning and implications. More exactly, Ali looks to ask questions about the role of parties in revolutionary politics, the effects of their weaknesses, and the factors that allow for international working-class organization. One of the problems the Bolsheviks ran into was the organizational weakness of European socialism and their own inability to help fledgeling European revolutions because of the Civil War in which they were embroiled. Exactly how the Bolshevik leadership and Red Army could have helped European revolutionaries is, for Ali, also not clear in two different ways. On the one hand, the earlier revolutionary extension of bourgeois liberalism through Napoleon's French Empire was not a model the Bolsheviks could adopt because socialism necessarily involves the self-emancipation of the working class. On the other, the Bolsheviks never effectively developed a proletarian or socialist military organization or doctrine. This was one of their dilemmas as they moved onto qualitatively new ground during the Civil War and in the face of a potential historic defeat. In refashioning the Red Army as something of a mirror of the Tsarist Army, its own revolutionary potential was limited. 
As Ali notes, instead of being seen as part of a broader emancipatory politics connected to the revolution, the Red Army increasingly fought the Civil War on the unfriendly territory of the countryside in which its key merit seemed to be only that it was not the White Army.

Second, sex and gender were another key dilemma that ultimately bounded revolutionary change. At the beginning of the Revolution, "[s]ocialism was the first political current to understand the oppression of women and to discuss it seriously within the movement" (243). The dilemma was that Lenin recognized the need for social and political activism but was not certain of the form this should take. According to Ali, Marx and Engels had more or less assumed that the matter would solve itself during and after the revolution. This was not the case. In addition to Lenin's uncertainty, female revolutionaries were slurred and subjected to harassment; their concerns were treated as matters of secondary importance. Moreover, these problems existed not simply on the conservative borderlands of the old Russian Empire but in male-dominated trade unions connected to Bolshevism. The end result was a "sexual Thermidor" (271) that rolled back women's revolutionary advances and the incredibly advanced perspectives on homosexuality.

Finally, Leninism emerged within a deeply pluralistic left defined by a range of different political perspectives, parties, and organizations. This included the active legacy of Marx and Engels and their efforts to forge a communist international as read through the lens of German socialism, a splintered Russian social democracy, rural social revolutionaries, and anarchism as well as national liberation movements, among others. For Ali, Leninism is not a refined political and/or philosophical position, nor was this the aim. Instead, Lenin drew on a range of different revolutionary traditions with the aim of establishing a programmatic political strategy. One of the bitter stories of the Russian Civil War and its aftermath is the constriction of a plural left and its reduction in the Soviet Union to an increasingly singularized ideological position. There are a range of reasons for this. Ali does not want us to see the demise of a plural left as somehow inherent in Leninism or the revolutionary politics of 1917. In fact, there is more than enough blame to go around, a significant part of which can be laid at the feet of capitalist intervention in the Russian Civil War and the isolation of the Soviet Union after the failure of the post-World War I European revolutions. Whether as cause or symptom, the narrowing of leftist debate and the increasingly rigid dynamics of thought that overtook the Soviet Union became a hallmark of Stalinist autocracy and violence.

There is much more to say about Dilemmas of Lenin, but the key point to take away is that this is a masterful study by a polished scholar and political activist. It is rigorous, nuanced, and about much more than Ali initially suggests. Dilemmas of Lenin is an engaged history that is never reductionist, open about its own questions and concerns, and clear in its perspective. One of the odd things about 1917 is the degree to which it has not attracted the kind of sustained historiographic attention that one might have imagined. Perhaps this is because it no longer fits with 
the Russian government's contemporary self-image and because it is so intricately connected to the rise of Stalinism. Ali's work illustrates the considerable merits of revisiting this issue and thinking it through in a more sustained way. Today's politics are, of course, not those of 1917 , but that would be a pretty simplistic conclusion and not the real lesson Ali might want us to take away. Instead of providing an easily "useable past," Ali has sketched out a radical leftist politics that requires care, consideration, thought, and attention to history. That alone is reason to read this book. 